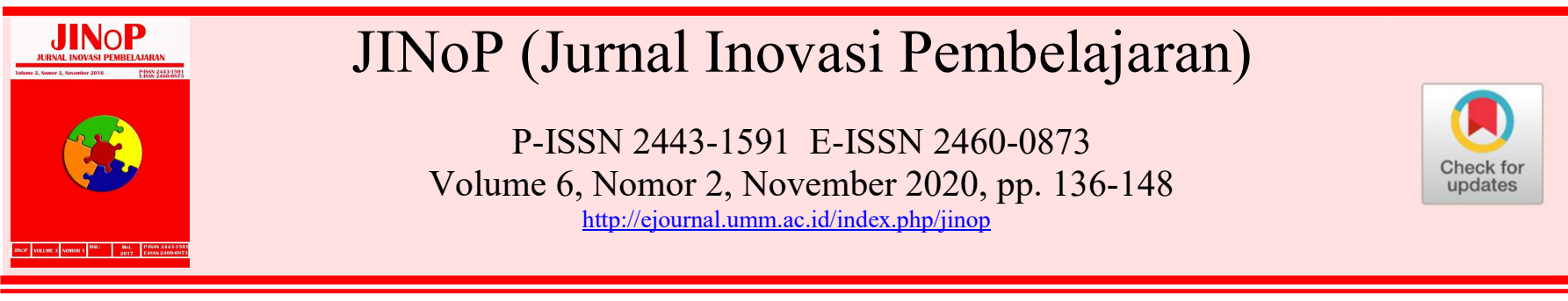

\title{
Model evaluasi ketercapaian kompetensi dasar Qur'an hadis berbasis kognitif pada pembelajaran pendidikan agama Islam
}

\author{
Uus Herman $^{1)^{*}}$, Chaerul Rochman ${ }^{2)}$, Maslani ${ }^{3)}$ \\ ${ }^{1}$ Program Doktor Pendidikan Islam, Pascasarjana, UIN Sunan Gunung Djati Bandung, Jalan \\ Cimencrang Cimenerang Kec. Gedebage Kota Bandung Jawa Barat Indonesia \\ ${ }^{2}$ Program Doktor Pendidikan Islam, Pascasarjana, UIN Sunan Gunung Djati Bandung, Jalan \\ Cimencrang Cimenerang Kec. Gedebage Kota Bandung Jawa Barat Indonesia \\ ${ }^{3}$ Program Doktor Pendidikan Islam, Pascasarjana, UIN Sunan Gunung Djati Bandung, Jalan \\ Cimencrang Cimenerang Kec. Gedebage Kota Bandung Jawa Barat Indonesia
}

uusherman2000@gmail.com*; rochmanchaerul@gmail.com; maslani@gmail.com

*Penulis Koresponden

\section{ABSTRAK}

Pesantren berkonstribusi besar dalam merealisasikan tujuan pendidikan nasional serta mencerdaskan kehidupan bangsa, salah satunya melalui model evaluasi ketercapaian kompetensi dasar (KD). Tujuan penelitian ini untuk menganalisis ketercapaian KD Qur'an-hadis berbasis kognitif pada pembelajaran pendidikan agama islam di satuan pendidikan muadalah TMI Pondok Pesantren Darussalam Sindangsari Kersamanah Garut. Jenis penelitian ini adalah deskriptif. Pengumpulan data melalui wawancara, observasi dan dokumentasi. Data dianalisis melalui analisis deskriptif. Hasil penelitian menunjukkan bahwa persentase ketercapaian nilai kompetensi dasar Qur'an-hadis berbasis kognitif dapat diungkapkan bahwa rata-rata ketercapaian kompetensi dasar pemahaman ayat alQur'an adalah $21,21 \%$; hafalan ayat alQur'an adalah $20,20 \%$; pemahaman hukum-hukum tajwid adalah 19,19\%; pemahaman hadis adalah $21,21 \%$; dan rata-rata ketercapaian kompetensi dasar no. 5 yang berkenaan dengan hafalan hadis adalah 19,19\%. Berdasarkan analisis ketercapaian KD Qur'an-hadis maka dapat disimpulkan bahwa, capaian KD mata pelajaran Qur'an-Hadis belum merata. KD Qur'an-hadis penjadi prioritas dalam pembelajaran Pendidikan Agama Islam dan Satuan Pendidikan Muadalah (SPM) Pondok Pesantren Darussalam, oleh karena itu proses pembelajaran seharusnya memprioritaskan tercapainya KD sebagai bahan evaluasi hasil pembelajaran.

Kata Kunci : Analisis ketercapaian; Kompetensi Dasar; Qur'an-Hadis; Kognitif.

\section{ABSTRACT}

Islamic boarding schools contributed in realizing the goals of national education and enrich the life of a nation, one of which is through the evaluation model for the achievement of basic competencies (KD). The purpose of this research was to analyze the achievement of cognitivebased KD quran-hadith in Islamic religious education lesson at the Muadalah Education Unit of the Darussalam Sindangsari Kersamanah Islamic Boarding School, Garut. The research employed descriptive method by collecting data through interviews, observation and documentation. The data were analyzed through descriptive analysis. The research results showed the percentage of achievement of the basic competency values of the cognitive-based quran-hadiths can be revealed that the average achievement of the basic competence in understanding the verses of the alquran is $21.21 \%$; memorization of the verse alquran is $20.20 \%$; understanding of the laws of recitation is $19.19 \%$; understanding of hadith is $21.21 \%$; and the average achievement of basic competencies no. 5 which is related to the hadith memorization is $19.19 \%$. Based on the analysis of the achievement of the KD quran-hadiths, it can be concluded that the KD achievements in the Qur'anHadith subjects are not evenly distributed. KD quran-hadith is a priority in the learning of Islamic Religious Education and Muadalah Education Unit Pondok Pesantren Darussalam. Therefore, the learning process should prioritize the achievement of $\mathrm{KD}$ as material for evaluating learning outcomes.

Keywords: Achievement Analysis; Basic Competence; Qur'an-Hadith; Cognitive. 
diunggah: 2019-06-01 , direvisi: 2020-05-08, diterima: 2020-11-20 ,dipublikasi: 2020-11-20

Copyright (c) 2020 Herman et al

This is an open access article under the CC-BY license

Cara sitasi: Herman, U., Rochman, C., \& Maslani, M. (2020). Model evaluasi ketercapaian kompetensi dasar Qur'an hadis berbasis kognitif pada pembelajaran pendidikan agama islam. JINoP (Jurnal Inovasi Pembelajaran), 6(2). doi:https://doi.org/10.22219/jinop.v6i2.8575

\section{PENDAHULUAN}

Salah satu jenis pendidikan islam tradisional di Indonesia yang merupakan tempat mendalami ilmu agama adalah pendidikan pesantren. Pesantren telah berdiri sejak ratusan tahun silam dan telah menjangkau hampir seluruh lapisan masyarakat muslim, serta telah diakui sebagai lembaga pendidikan islam yang berkonstribusi besar dalam merealisasikan tujuan pendidikan nasional serta mencerdaskan kehidupan bangsa.

Dalam mensikapi kemajuan sistem pendidikan nasional, pesantren berupaya mengimbangi sistem tersebut dengan mengaplikasikan sistem dan kebijakan pendidikan nasional pada sistem pendidikan dan pembelajaran yang ada di pesantren. Salah satu dari sistem tersebut adalah perumusan dan pelaksanaan standar kompetensi (SK) dan kompetensi dasar (KD) pada bahan-bahan ajar serta kurikulum pondok pesantren.

Pondok pesantren adalah lembaga pendidikan islam yang berasrama, selain itu Pondok pesantren merupakan lembaga pendidikan islam yang pertama di Indonesia. Pada mulanya kyai ingin mengajarkan ilmu agama kepada orang-orang yang ada di sekitar rumahnya, tetapi semakin berkembangnya waktu semakin banyak pula orang yang ingin menuntut ilmu agama. Ada pula yang datang dari luar daerah, karena masalah transportasi yang belum begitu memadai banyak orang yang menuntut ilmu yang kemudian menginap di rumah kyai. Hingga rumah kyai sendiri tidak memadai dan membangun asrama di sekitar rumah kyai.

Seiring perkembangan zaman pengelolaan pondok pesantrenpun dari segi penyelenggaraan pendidikan makin berkembang. Sebagian pondok pesantren menggunakan sistem madrasah/klasikal dan kurikulumnya menyesuaikan dengan kurikulum Pemerintah dengan menyelenggarakan MI, MTs, MA atau penyelenggaraan SD, SMP, dan SMA/SMK bahkan sampai Perguruan Tinggi, namun sebagian pesantren masih tetap mempertahankan sistem pendidikan khas pesantren secara mandiri baik kurikulumnya maupun proses pembelajaran dan pendidikannya.

Disadari bahwa selama ini perhatian dan pengakuan (recognition) pemerintah terhadap institusi pesantren khususnya yang tidak menyelenggarakan pendidikan Madrasah/Sekolah formal masih sangat minim, bahkan tamatan Persantren belum mendapat pengakuan (mu'adalah/ kesetaraan), sehingga sering menemui kesulitan untuk melanjutkan belajar ke jenjang pendidikan yang lebih tinggi maupun untuk melamar pekerjaan pada sektor formal. Padahal selama ini, masyarakat telah memberikan pengakuan terhadap kualitas lulusan Pesantren, dan bahkan sebagian dari lembaga pendidikan di luar negeri pun telah memberikan pengakuan kesetaraan (mu'adalah) terhadap pendidikan pondok pesantren (Hidayat, 2014).

Pesantren Muadalah merupakan salah satu arah baru kemajuan model pendidikan yang ada di Pondok Pesantren. Mu'adalah secara harfiah berarti 
penyetaraan juga merupakan bentuk pengakuan dari pemerintah terhadap keberadaan pondok pesantren secara umum. Bentuk pengakuan pemerintah tersebut adalah memberikan dorongan dari berbagai segi implementasi penyetaraan pondok pesantren tersebut dengan pendidikan formal pada umumnya, seperti pemberian standart isi, pengelolaan bahkan pengakuan akan eksistensi ijazah yang dikeluarkan pondok pesantren tersebut. Peraturan Menteri Agama Nomor 18 Tahun 2014 tentang Satuan Pendidikan Muadalah Pada Pondok Pesantren (PMA RI, 2014) : "Satuan pendidikan Mu'adalah pada pondok pesantren yang selanjutnya disebut satuan pendidikan muadalah adalah satuan pendidikan keagamaan islam yand diselenggarakan oleh dan berada di lingkungan pesantren dengan mengembangkan kurikulum sesuai kekhasan pesantren dengan basis kitab kuning atau dirasah islamiyah dengan pola pendidikan muallimin secara berjenjang dan terstruktur yang dapat disetarakan dengan jenjang pendidikan dasar dan menengah di lingkungan Kementrian Agama".

Hal itu sejalan dengan makna yang terkandung dalam Undang Undang Sistem Pendidikan Nasional Nomor 20 Tahun 2003 pasal 26 ayat 6 yang berbunyi: "Hasil pendidikan nonformal dapat dihargai setara dengan hasil program pendidikan formal setelah melalui proses penilaian penyetaraan oleh lembaga yang ditunjuk oleh Pemerintah atau pemerintah daerah dengan mengacu pada standar nasional pendidikan" (UU SISDIKNAS, 2009).

Secara terminologi, pengertian $m u$ 'adalah adalah suatu proses penyetaraan antara institusi pendidikan baik pendidikan di pondok pesantren maupun di luar pesantren dengan menggunakan kriteria baku dan mutu/kualitas yang telah ditetapkan secara adil dan terbuka. Selanjutnya hasil dari mu'adalah tersebut, dapat dijadikan dasar dalam meningkatkan pelayanan dan penyelenggaraan pendidikan di pondok pesantren.

Dalam konteks ini, dalam buku pedoman pesantren Mu'adalah yang diterbitkan oleh Kementrian Agama pada tahun 2009 (Choirul Fuad, 2009) diungkapkan bahwa: "Pondok pesantren mu'adalah yang terdapat di Indonesia terbagi menjadi 2 (dua) bagian; Pertama, pondok pesantren yang lembaga pendidikannya dimu'adalahkan dengan lembaga-lembaga pendidikan di luar negeri seperti Universitas al-Azhar Cairo Mesir, Universitas Umm al-Qurra Arab Saudi maupun dengan lembaga-lembaga non formal keagamaan lainnya yang ada di Timur Tengah, India, Yaman, Pakistan atau di Iran. Pondok pesantren-pondok pesantren yang mu'adalah dengan luar tersebut hingga saat ini belum terdata dengan baik karena pada umumnya mereka langsung berhubungan dengan lembaga-lembaga pendidikan luar negeri tanpa ada koordinasi dengan Depag RI maupun Departemen Pendidikan Nasional. Kedua, pondok pesantren mu'adalah yang disetarakan dengan Madrasah Aliyah dalam pengelolaan Depag RI dan yang disetarakan dengan SMA dalam pengelolaan Diknas. Keduanya mendapatkan SK dari Dirjen terkait".

Dari penjelasan di atas dapat dipahami bahwa jenis pesantren Mu'adalah di Indonesia ada dua jenis, yaitu pesantren Mu'adalah yang disetarakan dengan ma'had luar negeri telah tersohor namanya, seperti al Azhar di Kairo dan Universitas Umm al-Qurra Arab Saudi. Sedangkan jenis yang kedua yaitu, pesantren Mu'adalah. Satuan pendidikan muadalah pada pondok pesantren yang selanjutnya disebut satuan pendidikan muadalah adalah satuan pendidikan keagamaan Islam yang diselenggarakan oleh dan berada di lingkungan pesantren dengan mengembangkan kurikulum sesuai kekhasan pesantren dengan basis kitab 
kuning atau dirasah islamiyah dengan pola pendidikan muallimin secara berjenjang dan terstruktur yang dapat disetarakan dengan jenjang pendidikan dasar dan menengah di lingkungan Kementerian Agama (PMA RI, 2014), Dengan demikian kurikulumnya di setarakan dengan pengelolaan Madrasah Aliyah di bawah pengelolaan Departemen Agama ataupun pesantren Mu'adalah yang disetarakan dengan SMA yang pengelolaannya di bawah Departemen Pendidikan Nasional.

Permendiknas No.23 tahun 2006, tentang pengembangan standar kompetensi dasar menjelaskan, bahwa kompetensi adalah kemampuan bersikap, berfikir dan bertindak secara konsisten sebagai perwujudan dari pengetahuan, sikap dan keterampilan yang dimiliki siswa. Perpaduan antara pengetahuan, keterampilan nilai dan sikap yang direfleksikan dalam kebiasaan berfikir dan bersikap merupakan pengertian dari kompetensi. Kompetensi sering pula diartikan sebagai pengetahuan, wawasan, keterampilan dan kemampuan yang dikuasai seseorang yang telah menjadi bagian dari dirinya, sehingga seseorang dapat berbuat, bersikap dan berperilaku dengan kognitif, afektif dan psikomotorik yang baik dan bernilai. Hal tersebut di atas menunjukan bahwa sesungguhnya untuk melaksanakan pembelajaran dengan baik peserta didik harus dapat melaksanakan ranah kompetensi yang mencakup tugas, keterampilan, sikap dan apresiasi.

Kompetensi yang ingin dicapai dalam tujuan pembelajaran bukan hanya sekedar pemahaman akan materi pelajaran, akan tetapi, bagaimana pemahaman materi dan penguasaannya itu dapat mempengaruhi keseharian peserta didik baik dalam bertindak dan berprilaku. Kompetensi dasar adalah merupakan perincian atau penjabaran lebih lanjut dari standar kompetensi yang sangat penting bagi dan berguna untuk mengingatkan para guru seberapa jauh tuntutan target kompetensi yang harus dicapainya. Sementara itu Kompetensi kognitif adalah berupa konsep, fakta, prosedur, prinsip atau rumus dari body knowledge ilmu pengetahuan yang berkaitan dengan mata pelajaran.

Seorang pendidik harus tahu haluan pelajaran, artinya tahu apa yang harus diambil dan ditekankan, pada tiap-tiap pelajaran, dan apabila ia tidak tahu haluan atau tujuan tersebut, ia bisa meremehkan pelajaran, yang akhirnya bisa tersesat dan menyesatkan. Tugas pokok seorang pendidik bukan sekedar mengajar, bukan sekedar memberi ilmu, dan bukan sekedar membacakan, tetapi seorang pendidik harus selalu berdaya upaya/berusaha agar tujuan pelajaran dan pendidikan itu benar-benar menjadi milik peserta didik dan menjadi keyakinan serta pegangan hidupnya. Keberhasilan itu bisa dicapai dengan membuat rancangan konsep yang tertuang didalam standar kompetensi dasar pada setiap mata pelajaran yang akan menjadi sumber bahan ajar.

Pendidikan al-Qur'an dan Hadis di Madrasah pada umumnya dan pondok pesantren pada khususnya, sebagai landasan yang integral dari pendidikan Agama, meskipun ia bukan satu-satunya faktor yang menentukan dalam pembentukan watak dan kepribadian peserta didik, tetapi secara substansial mata pelajaran alQur'an dan Hadis memiliki kontribusi dalam memberikan motivasi kepada peserta didik untuk mempraktekkan pengetahuan dan nilai-nilai keyakinan kegamaan (tauhid) dan Ahlaqul karimah dalam kehidupan sehari-hari.

Mata pelajaran al-Qur'an Hadis adalah bagian dari ruang lingkup bahan pelajaran Pendidikan Agama Islam pada satuan pendidikan, (Abid, 2017). Tarbiatul Mu'allimin al-Islamiah (TMI) Pondok Pesantren Darussalam, pelajaran al-Qur'an Hadis bertujuan untuk memberikan motivasi, bimbingan, pemahaman, kemampuan dan penghayatan terhadap isi yang terkandung dalam al-Qur'an dan Hadis sehingga 
dapat diwujudkan dalam perilaku sehari-hari sebagai manifestasi iman dan taqwa kepada Allah SWT. serta berahklak mulia.

Berdasarkan pemaparan di atas, penulis mencoba untuk menganalisis sejauh ma na ketercapaian kompetensi dasar Al-Qur'an dan Hadis berbasis kognitif pada pembelajaran pendidikan agama islam, merancang kompetensi dasar pada materi Al-Qur'an dan hadis sebagai salah satu dari komponen materi pendidikan agama islam di Satuan pendidikan Muadalah TMI Pondok Pesantren Darussalam Sindangsari Kersamanah Garut dengan objek analisis peserta didik kelas XI Satuan pendidikan Muadalah TMI Pondok Pesantren Darussalam Sindangsari Kersamanah Garut. Kegiatan yang mencoba menjawab dan mengatasi kendala dan permasalahan dalam penilaian hasil serta ketercapaian kompetensi dasar salah satu dari materi pelajaran PAI.

Penelitian sebelumnya dilakukan oleh Dwi Astuti, dkk (2020) dengan judul "Model Penjaminan Mutu Ketercapaian Kompetensi Dasar dalam Sistem Pembelajaran Online pada Situasi Work From Home (WFH)" Model penjaminan mutu ketercapaian KD untuk mata pelajaran pendidikan agama menempuh sistem sajian melalui youtube dan wa group yang diseleksi dalam dua tahapan agar mutu pembelajaran tergaransi. Model penjaminan mutu disesuaikan feasiblitasnya melalui FGD yang diadakan dengan melibatkan stakeholders.

Isi dari UU No. 20 Tahun 2003 tentang Sistem Pendidikan Nasional, menyatakan bahwa pendidikan nasional berfungsi mengembangkan kemampuan dan membentuk watak serta peradaban bangsa yang bermartabat dalam rangka mencerdaskan kehidupan bangsa, bertujuan untuk berkembangnya potensi peserta didik agar menjadi manusia yang beriman dan bertakwa kepada Tuhan Yang Maha Esa, berakhlak mulia, sehat, berilmu, cakap, kreatif, mandiri, dan menjadi warga negara yang demokratis serta bertanggung jawab. Untuk mencapai tujuan tersebut, salah satu bidang studi yang harus dipelajari oleh peserta didik di madrasah adalah Pendidikan Agama Islam, yang dimaksudkan untuk membentuk peserta didik menjadi manusia yang beriman dan bertakwa kepada Tuhan Yang Maha Esa serta berakhlak mulia (UU SISDIKNAS, 2009).

Pendidikan Agama Islam di Madrasah dan Pondok Pesantren terdiri atas empat mata pelajaran, yaitu: Al-Qur'an-Hadis, Akidah-Akhlak, Fiqih, dan Sejarah Kebudayaan Islam. Masing-masing mata pelajaran tersebut pada dasarnya saling terkait, isi mengisi dan melengkapi. Al-Qur'an-hadis merupakan sumber utama ajaran Islam, dalam arti ia merupakan sumber akidah-akhlak, syari'ah/fiqih (ibadah, muamalah), sehingga kajian berada di setiap unsur tersebut.

Pendidikan Agama Islam (PAI) di Madrasah dan Pondok Pesantren yang terdiri atas empat mata pelajaran tersebut memiliki karakteristik sendiri-sendiri. AlQur'an-hadis, menekankan pada kemampuan baca tulis yang baik dan benar, memahami makna secara tekstual dan kontekstual, serta mengamalkan kandungannya dalam kehidupan sehari-hari. Materi Akidah Akhlak terfokus pada pembahasan penanaman keimanan dan akidah yang benar serta sifat-sifat terpuji yang garus dimiliki oleh anak didik.

Mata pelajaran Al-Qur'an-Hadis pada satuan pendidikan muadalah TMI Pondok Pesantren Darussalam adalah salah satu mata pelajaran PAI yang menekankan pada kemampuan membaca dan menulis al-Qur'an dan hadis dengan benar, serta hafalan terhadap surat-surat pendek dalam al-Qur'an, pengenalan arti atau makna secara sederhana dari surat-surat pendek tersebut dan hadis-hadis tentang akhlak terpuji untuk diamalkan dalam kehidupan sehari-hari melalui 
keteladanan dan pembiasaan. Secara substansial, mata pelajaran al-Qur'an-Hadis memiliki konstribusi dalam memberikan motivasi kepada seluruh peserta didik untuk mencintai kitab sucinya, mempelajari dan mempraktikkan ajaran dan nilainilai yang terkandung dalam al-Qur'an-Hadis sebagai sumber utama ajaran Islam dan sekaligus menjadi pegangan dan pedoman hidup dalam kehidupan sehari-hari. Materi Al-Quran-Hadis juga mendorong tumbuhnya kajian tentang pengembangan bahasa Arab

Kompetensi Dasar adalah pengetahuan, keterampilan dan sikap minimal yang harus dicapai oleh siswa untuk menunjukkan bahwa sesungguhnya siswa telah menguasai standar kompetensi yang telah ditetapkan denngan sebaik-baiknya, oleh karena itulah maka kompetensi dasar adalah penjabaran-penjabaran dari standar kompeten (Senjaya, 2008) si. Ketercapaian KD ditandai oleh perubahan perilaku yang dapat diukur yang mencakup sikap, pengetahuan, dan keterampilan yang disebut dengan istilah indikator. Indikator ini dikembangkan harus sesuai dengan karakteristik peserta didik, mata pelajaran, satuan pendidikan, potensi daerah dan dirumuskan dalam kata kerja operasional yang terukur dan/atau dapat diobservasi. Indikator adalah penjabaran dari kompetensi dasar yang menunjukkan tanda-tanda perbuatan dan respon yang dilakukan atau ditampilkan oleh peserta didik (Mulyasa, 2007). Indikator adalah tanda ataupun ciri yang menunjukkan siswa telah mampu memenuhi standar kompetensi yang diterapkan/berlaku, (Darwin, 2018). Menurut $\mathrm{KBBI}$, Indikator $/ \mathrm{in} \cdot \mathrm{di} \cdot \mathrm{ka} \cdot \mathrm{tor} / \mathrm{n}$ sesuatu yang dapat memberikan (menjadi) petunjuk atau keterangan: seseorang yang akan melakukan suatu pekerjaan sebaiknya menggunakan -yang sudah ada; kenaikan harga dapat menjadi-adanya inflasi, (KBBI, 2018) . Indikator adalah alat pemantau (sesuatu) yg dapat memberikan petunjuk atau keterangan (Sugono, 2008). Menurut WHO, Pengertian Indikator adalah variabel yang bisa membantu kita dalam kegiatan pengukuran berbagai macam perubahan yang terjadi baik secara langsung ataupun tidak langsung. (WHO, 1981).

Rumusan indikator dalam sistem pendidikan nasional, menggunakan klasifikasi hasil belajar Benyamin Bloom dalam (Sudjana, 2009), yang membaginya menjadi tiga ranah pengukuran yaitu ranah kognitif, ranah afektif dan ranah psikomotorik. Dan yang menjadi substansi pembahasan adalah kompetensi dasar dalam ranah kognitif. Ranah kognitif adalah ranah yang mencakup kegiatan mental (otak). Menurut Bloom, segala upaya yang menyangkut aktivitas otak adalah termasuk dalam ranah kognitif. Ranah kognitif mencakup kemampuan berfikir, yang terdiri dari kemampuan menghafal, memahami, mengaplikasi, menganalisis, mensintesis, dan kemampuan mengevaluasi. Proses pendidikan melalui peran dan fungsi pemangku kepentingan dapat dilakukan melalui konsep pembelajar yang melibatkan wali siswa di semua kegiatan sekolah, terutama dalam proses pembelajaran berkala dengan sistem 1 minggu tatap muka, 1 pelajaran secara bergantian. Apresiasi, simpati, dan empati para pemangku kepentingan pendidikan, serta apresiasi anak-anak atas nilai kemanusiaan, semakin baik (Zaini, 2018).

Menurut Bloom dalam (Sudijono, 2009), menjelaskan bahwa dalam ranah kognitif itu terdapat enam aspek proses berfikir, mulai dari aspek terendah sampai dengan aspek yang paling tinggi. Enam aspek tersebut adalah pengetahuan /hafalan/ingatan (knowledge), pemahaman, penerapan (application), analisis (analysis), sintesis (syntesis), dan penilaian/ evaluasi (evaluation).

Sementara itu, aspek mata pelajaran pada pendidikan agama islam tidak hanya dilihat dari aspek materi atau substansi pelajaran yang hanya mencakup 
aspek kognitif (pengetahuan) saja, akan tetapi lebih luas dari itu. Aspek mata pelajaran PAI mencakup aspek afektif dan psikomotorik. Ruang lingkup mata pelajaran PAI meliputi keserasian, keselarasan dan keseimbangan antara: hubungan manusia dengan Allah SWT, hubungan manusia dengan sesama manusia, hubungan manusia dengan dirinya sendiri, hubungan manusia dengan makhluk lain dan lingkungannya. Ruang lingkup bahan pelajaran pendidikan agama Islam untuk SMA/SMK dan yang sederajat meliputi lima aspek, (Ramayulis, 2005) yaitu:

1. Al-Quran/Hadis; menekankan pada kemampuan membaca, menulis, dan menerjemahkan dengan baik dan benar;

2. Keimanan; menekankan pada kemampuan memahami dan mempertahankan aqidah dan keyakinan, serta menghayati, mengimani dan mengamalkan nilainilai ayat al-Qur'an dan hadis sesuai dengan kemampuan peserta didik;

3. Akhlak; menekankan pada pengamalan akhlak mulia dan menghindari akhlak tercela;

4. Fiqih/Ibadah; menekankan pada cara pengamalan ibadah dan mu'amalah yang baik dan benar;

5. Tarikh dan Kebudayaan Islam; menekankan pada kemampuan mengambil pelajaran (ibrah) dari peristiwa- peristiwa dalam bersejarah (Islam), meneladani tokoh-tokoh muslim yang berprestasi, dan mengaitkannya dengan fenomenafenomena sosial, untuk melestarikan dan mengembangkan kebudayaan dan peradaban Islam.

Kurikulum 2013 dirancang untuk mengembangkan rasa ingin tahu, kreativitas, kerjasama dengan kemampuan kognitif/intelektual dan psikomotorik (Permendikbud, 2013) Hal itu menjadi acuan dalam mengindentifikasi materi pembelajaran yang menunjang pencapaian kompetensi dasar pendidikan agama islam dengan mempertimbangkan:

1) potensi peserta didik,

2) relevansi dengan karakteristik daerah,

3) tingkat perkembangan fisik, intelektual, emosional, sosial, dan spritual peserta didik,

4) kebermanfaatan bagi peserta didik,

5) struktur keilmuan,

6) aktualitas, kedalaman, dan keluasan materi pembelajaran,

7) relevansi dengan kebutuhan peserta didik dan tuntutan lingkungan; dan,

8) alokasi waktu.

Tujuan penelitian ini untuk menganalisis ketercapaian KD Qur'an-hadis berbasis kognitif pada pembelajaran Pendidikan Agama Islam di kelas XI Satuan Pendidikan Muadalah TMI Pondok Pesantren Darussalam Sindangsari Kersamanah Garut. Penelitian ini mengelaborasi mekanisme pembelajaran Pendidikan Agama Islam di pondok pesantren Darussalam sebagai penyelenggara pendidikan modern, memberikan inovasi tentang perumusan KD mata pelajaran Qur'an-hadist, serta memberikan wawasan dan pengetahuan baru tentang KD Qur'an-hadis berbasis kognitif pada Satuan Pendidikan Muadalah TMI Pondok Pesantren Darussalam Garut.

\section{METODE}

Penelitian ini merupakan penelitian kualitatif, dasar penelitian kualitatif adalah data alamiah yang merupakan kata-kata dalam mendeskripsikan objek atau 
tema yang diteliti dan dianalisis melalui kegiatan pengumpulan data dari latar yang alami (Rofi'uddin, 1996). Ciri-ciri yang menjadi dasar dari penelitian kualitatif adalah, (1) data yang dikaji adalah data verbal dan nonverbal yang dapat menghasilkan informasi relevan yang dibutuhkan peneliti, (2) data diperoleh dari data alamiah baik berupa tutur kata maupun perbuatan yang telah dilakukan, (3) data dianalisis secara induktif pada saat data yang dibutuhkan telah terkumpul, (4) instrumen utama dalam hal ini adalah peneliti itu sendiri, (5) penekanan penelitian tidak hanya pada hasil melainkan juga pada proses, (6) makna menjadi tekanan utama. Bogdan dan Biklen: 1982 dalam (Moleong, 2007).

Jenis penelitian ini adalah penelitian deskriptif yang menggambarkan kondisi yang terjadi di lapangan. Sejalan dengan pendapat (Sukamdinata, 2010), yang menyatakan bahwasanya model penelitian deskriptif dilakukan untuk menggambarkan baik yang bersifat alamiah atau buatan manusia.

Sumber data pada penelitian ini adalah siswi kelas XI pada Satuan Pendidikan Muadalah Tarbiyatul Mu'allimin Al-Islamiyah (TMI) Pondok Pesantren Darussalam Sindangsari Kersamanah Garut Jawa Barat Indonesia. Guru kelas XI Satuan Pendidikan Muadalah Tarbiyatul Mu'allimin Al-Islamiyah (TMI) Pondok Pesantren Darussalam, sebagai informan utama dalam kegiatan penugasan di sekolah.

Data pada penelitian ini dapat berupa kata-kata maupun tulisan yang berasal dari sumber yang diamati atau diteliti. Pengumpulan data pada penelitian ini menggunakan tiga teknik, diantaranya adalah sebagai berikut:

\section{a. Wawancara}

Wawancara adalah teknik yang dilakukan melalui kegiatan tanya jawab dengan informan. Wawancara dapat dilakukan secara terstruktur dan tidak terstruktur baik dengan tatap muka (face toface) atau menggunakan alat komunikasi lain, (Sugiono, 2012). Pada wawancara terstruktur ini digunakan sebagai teknik pengumpulan data, apabila peneliti atau pengumpul data telah mengetahui dengan pasti tentang informasi apa yang akan diperoleh. Sedangkan wawancara tidak Terstruktur adalah wawancara yang bebas di mana peneliti tidak menggunakan pedoman wawancara yang telah tersusun secara sistematis dan lengkap untuk pengumpulan datanya. hanya berupa garis-garis besar permasalahan yang akan ditanyakan. Wawancara dilakukan berdasarkan pedoman yang telah dibuat sebelumnya. Wawancara digunakan sebagai teknik pengumpulan data apabila peneliti ingin mengetahui hal dari subjek penelitian yang lebih dalam. Wawancara dilakukan kepada guru yang mengajar kelas XI tentang capaian kompetensi dasar pada materi PAI Qur'an-hadis

b. Observasi,

Observasi adalah teknik pengumpulan data yang dilakukan untuk memperoleh segala sesuatu yang berkaitan dengan pelaksanaan pembelajaran dan capaian kompetensi dasar. Observasi adalah suatu teknik pengumpulan data dengan mengadakan pengamatan terhadap kegiatan yang sedang berlangsung untuk memperoleh informasi yang dibutuhkan (Sukamdinata, 2010). Bungin dalam bukunya Penelitian Kualitatif(Bungin, 2007) mengemukakan beberapa bentuk observasi yang dapat digunakan dalam penelitian kualitatif, yaitu observasi partisipasi, observasi tidak terstruktur, dan observasi kelompok tidak terstruktur. Observasi partisipasi (participant observation) adalah metode pengumpulan data yang digunakan untuk menghimpun data penelitian melalui pengamatan dan pengindraan dimana observer atau peneliti benar-benar 
terlibat dalam keseharian responden. Observasi tidak berstruktur adalah observasi yang dilakukan tanpa menggunakan guide observasi. Pada observasi ini peneliti mengembangkan daya penelitian dalam meneliti suatu objek. Observasi kelompok adalah observasi yang dilakukan secara berkelompok terhadap suatu atau beberapa objek sekaligus

c. Dokumentasi,

Dokumentasi adalah salah satu metode pengumpulan data kualitatif dengan melihat atau menganalisis dokumen-dokumen yang dibuat oleh subjek sendiri atau oleh orang lain tentang subjek. Hasil observasi dan wawancara lebih obyektif jika didukung adanya dokumentasi. Dokumentasi adalah sebuah catatan peristiwa yang telah terjadi yang mana bisa berupa foto, gambar, biografi, catatan tertulis.

Proses pengumpulan data ini melalui beberapa tahapan yang setiap tahapan tersebut saling terkait satu sama lain. Terdapat lima tahapan proses pengumpulan data kualitatif (1) Melakukan identifikasi Subjek/ Partisipan, (2) lokasi Penelitian (Site). Creswell dalam (Herdiansyah, 2010) mengatakan bahwa sebagai seorang peneliti kualitatif, harus benar-benar matang dalam melakukan identifikasi partisipan dan lokasi penelitian sebagai pondasi awal penelitian yang akan dilakuan, (3) mencari akses menuju subjek/partisispan penelitian dan lokasi penelitian, (4) menentukan jenis data yang akan dicari/diperoleh, dan (5) mengembangkan atau menentukan instrumen/metode pengumpulan data.

Dalam menentukan instrument metode pengumpulan data, hal yang perlu diingat adalah bahwa dalam penelitian kualitatif lebih bersifat fleksibel dibandingkan dengan metode lainnya. Beberapa hal yang diperhatikan dalam pengumpulan data untuk penelitian kualitatif ini diantaranya, penelitian dilakukan lebih dari satu kali, dalam melakukan pengumpulan data selalu disesuaikan dengan situasi alamiah, dan melakukan probing terhadap simbol (Probing adalah proses eksplorasi lebih dalam terhadap suatu hal yang dirasa perlu untuk diungkap). Pemgumpulan data tentang capaian kompetensi dasar pada bahan ajar Qur'an-hadis dan berbagai peristiwa dalam proses pembelajaran PAI, yang menjadi unsur Kompetensi dasar Qur'an-hadis berbasis kognitif adalah (1) faham ayat alQur'an, (2) hafal ayat al-Qur'an, (3) faham hukum tajwid, (4) faham hadis dan (5) hafal hadis. Data yang diperoleh melalui metode pengumpulan data yang akan dikelola dan dianalisis secara deskriptif kualitatif dan kuantitatif.

\section{HASIL DAN PEMBAHASAN}

Produk yang dikembangkan dan diteliti adalah analisis ketercapaian kompetensi dasar quran-hadis kelas XI berbasis kognitif. Berdasakan hasil pengumpulan data didapatkan hasil sebagai berikut:

(1) Kompetensi Dasar yang harus dicapai siswa terdiri dari kemampuan membaca dan menulis Qur'an surat al-Hujurat 49:12 dan Hadis Rasulullah SAW. tentang Husnudzan dengan baik dan benar, memahami makna secara tekstual dan kontekstual, serta mengamalkan kandungannya dalam kehidupan sehari-hari. Materi Akidah Akhlak terfokus pada pembahasan penanaman keimanan dan akidah yang benar serta sifat-sifat terpuji yang harus dimiliki oleh peserta didik, Menerjemahkan kandungan al-Qur'an surat al-Hujurat 49:12 dan Hadis Rasulullah saw. tentang Husnudzan dengan baik dan benar, memahami hukum tajwid serta menganalisa contoh dari hadis tentang husnudzon. 
(2). Profil ketercapaian komposisi kualifikasi kompetensi kognitif siswi

Profil ketercapaian 5 (lima) komposisi kualifikasi kompetensi kognitif siswi pada Satuan Pendidikan Muadalah Pondok Pesantren, dapat ditunjukkan melalui gambar 1 berikut ini.

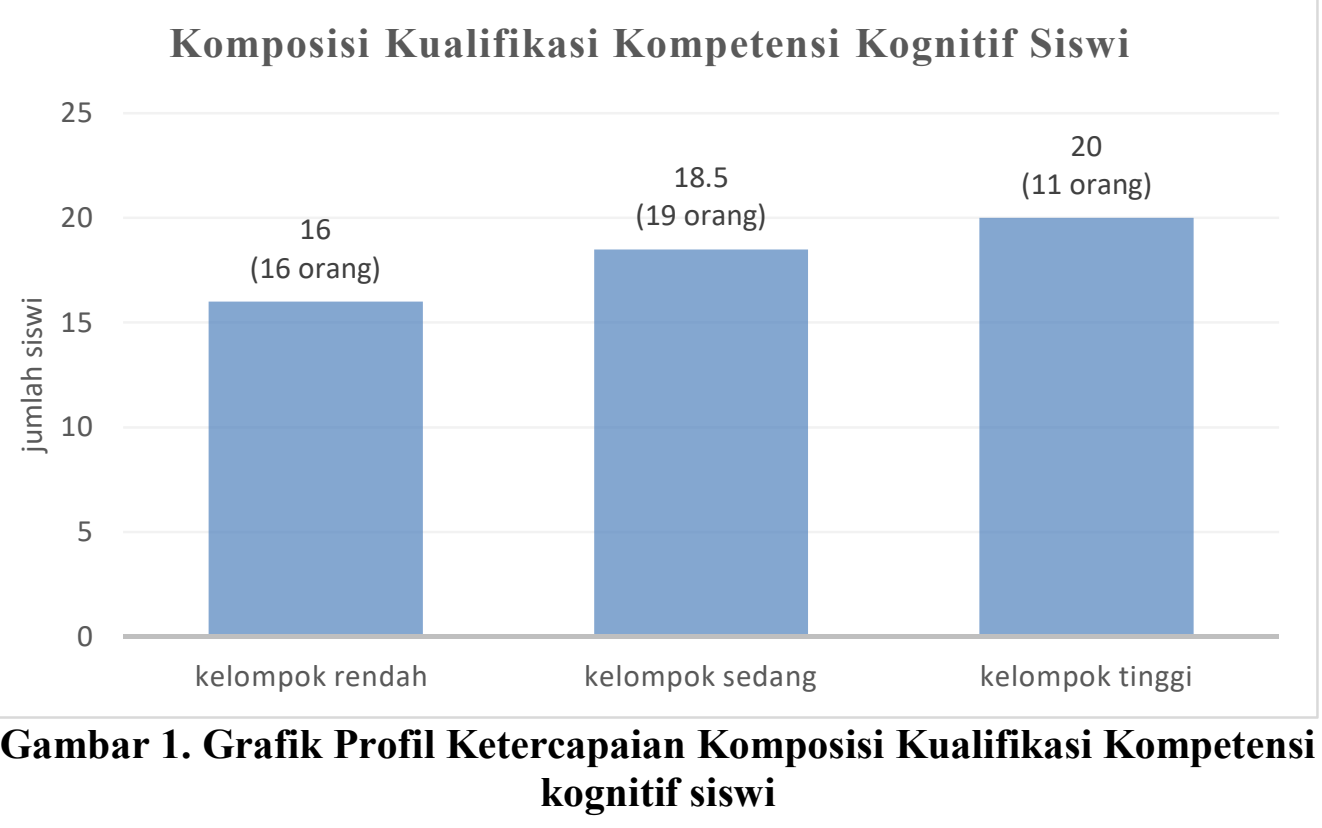

Nilai rata-rata kualifikasi ketercapaian kompetensi dasar berbasis kognitif dikelompokan menjadi tiga kelompok, yaitu kelompok rendah, kelompok sedang dan kelompok tinggi. Pada kelompok rendah rata-rata ketercapaian kompetensi dasar berbasis kognitif adalah 16 yang terdiri dari 16 orang siswi, kelompok kelompok sedang rata-rata ketercapaian kompetensi dasar berbasis kognitif adalah 18.5 yang terdiri dari 19 orang siswi, dan kelompok tinggi rata-rata ketercapaian kompetensi dasar berbasis kognitif adalah 20 yang terdiri dari 11 orang siswi, dari jumlah siswi kelas XI 46 orang.

Kompetensi Dasar (KD) merupakan kompetensi yang dipelajari peserta didik untuk suatu mata pelajaran di kelas tertentu. Untuk menilai penguasaan kompetensi sesuai dengan tuntutan dalam Standar Kompetensi (SK) dan Kompetensi Dasar (KD), maka guru harus melakukan evaluasi dengan berbagai cara (Salamah, 2018).

(3) Hasil komunikasi/wawancara dengan siswa dan guru. Setelah mendapatkan data profil tersebut di atas (grafik 1) selanjutnya dikomunikasikan degan siswa dan guru Hasil komunikasi dengan siswa yang masuk dalam kategori rendah, ternyata yang menyebabkan rendahnya rata-rata capaian kompetensi dasar adalah adanya kesulitan dalam pemahaman dan penerapan hukum tajwid dalam membaca alQuran serta kesulitan peserta didik menghafal hadis. Maka guru memberikan saran kepada siswa dalam penerapan ilmu dan hukum-hukum tajwid pada bacaan alQur'an harus melalui proses pembiasaan dan praktik. Kemudian dalam kesulitan menghafal hadis pendidik memberikan saran untuk belajar menghafal tadriji, yaitu menghafal secara bertahap menghapal dimulai dari kalimat ke kalimat yang lain, mengulang-ulang hafalan, sampai kepada penghafalan hadis secara keseluruhan dan proses menghapal harus dibarengi dengan penuh kesabaran.

(4). Analisis Kesulitan ketercapaian Kompetensi Dasar Qur'an-hadis berbasis kognitif. Hasil analisis ketercapaian kompetensi dasar Qur'an-hadis dalam ranah 
kognitif dilakukan pula simulasi soal-soal yang harus dijawab oleh siswa. Kemudian guru melakukan penilaian dari seluruh lembar jawaban siswa yang terdiri dari empat puluh enam siswi dan menghasilkan data Pada gambar 2.

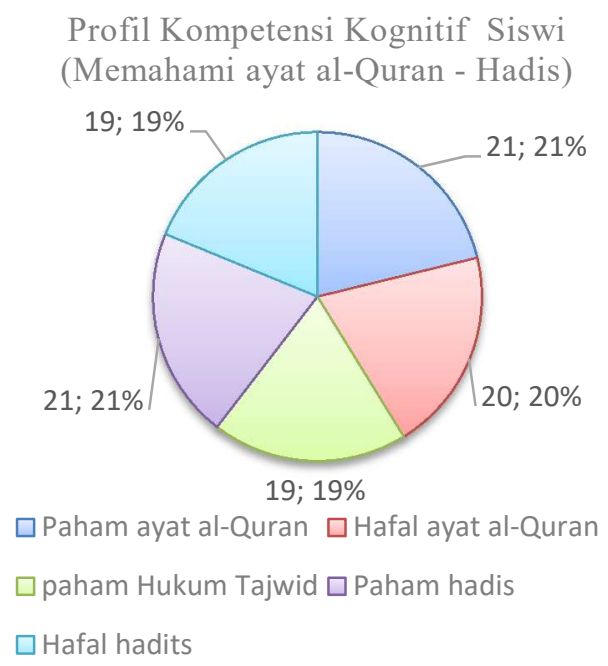

\section{Gambar 2. Persentase Komposisi Kompetensi Kognitif Siswi dalam Memahami Kompetensi Dasar Qur'an-Hadis}

Dari gambar di atas diketahui bahwa persentase ketercapaian nilai kompetensi dasar Qur'an-hadis berbasis kognitif dapat diungkapkan bahwa ratarata ketercapaian kompetensi dasar pemahaman ayat alQur'an adalah 21,21\%; hafalan ayat alQur'an adalah 20,20\%; pemahaman hukum-hukum tajwid adalah $19,19 \%$; pemahaman hadis adalah $21,21 \%$; dan rata-rata ketercapaian kompetensi dasar nomor 5 yang berkenaan dengan hafalan hadis adalah 19,19\%

Dari pemaparan di atas dapat dijelaskan bahwa rata-rata tertinggi dari ketercapaian kompetensi dasar Qur'an-hadis berbasis kognitif adalah terdapat pada KD pemahaman al-Qur'an, hafalan Qur'an, dan pemahaman hadis. Dengan nilai rata-rata di atas $20 \%$. Rata-rata ter rendah dari ketercapaian KD Qur'an-hadis berbasis kognitif adalah terdapat pada KD nomor tiga yaitu kompetensi dasar penguasaan hukum tajwid dan hafalan hadis, nilai rata-rata $19.19 \%$.

Bila dilihat dari sisi rata-rata ketercapaian kompetensi dasar Qur'an-hadis berbasis kognitif dengan berdasarkan pada pemaparan di atas, Capaian Kompetensi Dasar mata pelajaran Qur'an-hadis belum merata, Menurut Dwi Astuti (2020) guru memantau setiap proses, kemajuan, kelebihan, kekurangan serta memperbaiki hasil belajar peserta didik dengan evaluasi hasil belajar yang dilakukan secara berkesinambungan. Pemilihan metode yang tepat dalam penilaian akan berpengaruh dalam validitas dan objektivitas hasil penilaian yang berpengaruh pada kualitas pendidikan.

Model evaluasi ketercapaian KD berbasis kognitif ini menjadi bagian yang sangat penting pada Pendidikan Agam Islam di Satuan Pendidikan Muadalah TMI Pondok Pesantren Darussalam Sindangsari Kersamanah Garut. Meskipun hasil observasi dan wawancara menunjukkan pada awalnya guru-guru merasa kesulitan dalam pelaksanaan pembelajaran serta pencapaian KD, namun itu memberikan alternatif kepada guru tentang solusi bagai mana pelajaran bisa benar-benar diserap 
oleh peserta didik dan selanjutnya dapat diaplikasikan dalam bersikap dan berperilaku dalam kehidupan sehari-hari.

\section{SIMPULAN}

Berdasarkan analisis proses pelaksanaan pembelajaran dan proses pencapaian kompetensi dasar pada mata pelajaran Qur'an-hadis, maka diperoleh kesimpulan bahwa:

Capaian Kompetensi Dasar mata pelajaran Qur'an-Hadis belum merata, ratarata tertinggi dari ketercapaian kompetensi dasar Qur'an-hadis berbasis kognitif adalah terdapat pada KD pemahaman al-Qur'an, hafalan Qur'an, dan pemahaman hadis, dengan nilai rata-rata di atas $20 \%$. Sedangkan rata-rata terrendah pada KD penguasaan hukum tajwid dan hafalan hadis, nilai rata-rata $19.19 \%$. KD Qur'anhadis menjadi prioritas dalam pembelajaran Pendidikan Agama Islam dan Satuan Pendidikan Muadalah (SPM) Pondok Pesantren Darussalam. Oleh karena itu, proses pembelajaran seharusnya memprioritaskan tercapainya KD sebagai bahan evaluasi hasil pembelajaran.

\section{DAFTAR PUSTAKA}

Abid, M. N. (2017, Desember 19). Dosen Muslim.com. Retrieved from Dosen Muslim.com: $\quad$ https://dosenmuslim.com/pendidikan/ruang-lingkuppendidikan-agama-islam/\#_ftn2

Bungin, B. (2007). Penelitian Kualitatif. Jakarta: Prenada Media Group.

Choirul Fuad, Y. (2009). Pedoman Pesantren Muadalah. Jakarta: Direktur Jenderal Pendidikan Diniyah dan Pondok Pesantren.

Darwin, S. (2018, 9 20). Pengertian Indikator Secara Umum dan Menurut Para Ahli serta Jenis-Jenis Indikator Lengkap. Retrieved from Pengertian Indikator Secara Umum dan Menurut Para Ahli serta Jenis-Jenis Indikator Lengkap: https://www.pelajaran.co.id/2018/20/pengertian-indikatorsecara-umum-dan-menurut-ahli-serta-jenis-jenis-indikator.html

Dwi Astuti, Eko Supriyanto, Muthoifin (2020), Model Penjaminan Mutu Ketercapaian Kompetensi Dasar dalam Sistem Pembelajaran Online pada Situasi Work From Home (WFH) PROFETIKA, Jurnal Studi Islam, Vol.21, No. 1, Special Issue 2020: 129-139

Herdiansyah, H. (2010). Metodologi Penelitian Kualitatif untuk Ilmu-Ilmu Sosial. Jakarta: Salemba Humanika.

Hidayat, A. d. (2014). Kebijakan Pesantren Mu'adalah. Jurnal Pendidikan Islam, 185.

KBBI. (2018, 9 20). Pengertian Indikator secara umum dan menurut para ahli serta jenis-jenis indikator. Retrieved from Pengertian Indikator secara umum dan menurut para ahli serta jenis-jenis indikator: https://www.pelajaran.co.id/2018/20/pengertian-indikator-secara-umumdan-menurut-ahli-serta-jenis-jenis-indikator.html

Moleong, L. (2007). Metode Penelitian Kualitatif. Bandung: Remaja Rosdakarya. Mulyasa, E. (2007). Standar Kompetensi dan Sertifikasi Guru. Bandung: Remaja Rosdakarya. 
Permendikbud. (2013, 2 21). Bahan Ajar Kelas IV Mengacu Kurikulum 2013. Retrieved from Bahan Ajar Kelas IV Mengacu Kurikulum 2013: https://www.fmedia.co.id/bahan-ajar-kelas-iv-mengacu-kurikulum-2013/

Permendiknas (2006,23). Pengembangan Standar Kompetensi Dasar.

PMA RI. (2014, Juli 14). Peraturan Menteri Agama Republik Indonesia Nomor 18 Tahun 2014 Tentang Satuan Pendidikan Muadalah Pondok Pesantren Bab 1 Pasal 1. Retrieved from Peraturan Menteri Agama Republik Indonesia Nomor 18 Tahun 2014 Tentang Satuan Pendidikan Muadalah Pondok Pesantren Bab 1 Pasal https://kalteng.kemenag.go.id/file/file/HumasKalteng/lrim1466049995.pdf Ramayulis. (2005). Metodologi Pendidikan Agama Islam. Jakarta: Kalam Mulia.

Rofi'uddin. (1996). Penilaian Pengajaran Bahasa Indonesia di Sekolah Dasar. Malang: PPS IKIP Malang.

Salamah, U. (2018). Penjaminan Mutu Penilaian Pendidikan. EVALUASI:Jurnal Manajemen Pendidikan Islam, 2(1), 274-293.

Senjaya, W. (2008). Strategi Pembelajaran; Berorientasi Standar Proses Pendidikan. Jakarta: Kencana Prenada Media Group.

Sudijono, A. (2009). Pengantar evaluasi pendidikan. Jakarta: Rajagrafindo.

Sudjana, N. (2009). Penilaian Hasil Proses Belajar Mengajar. Bandung: PT. Remaja Rosdakarya.

Sugiono. (2012). Penelitian Kuantitatif kualitatif dan R\&D. Bandung: Alfabeta. Sugono, D. (2008). Kamus Bahasa Indonesia. Jakarta: Pusat Bahasa.

Sukamdinata, N. S. (2010). Metode Penelitian Pendidikan. Bandung: Remaja Rosdakarya.

UU SISDIKNAS, N. 2. (2009). Undang-undang Sistem Pendidikan Nasional Nomor 20 Tahun 2003 Pasal 26 ayat 6. Jakarta: Fokus Media.

WHO. (1981). Retrieved from pengertian-indikator-secara-umum-dan-menurutahli-serta-jenis-jenis-indikator.:

https://www.pelajaran.co.id/2018/20/pengertian-indikator-secara-umumdan-menurut-ahli-serta-jenis-jenis-indikator.html

Zaini, M. d. (2018). Penerapan Konsep Trilogy +1 Learner dalam Menciptakan Pendidikan HumanisMelalui Peningkatan Peran dan Fungsi Stakeholders Pendidikan di SD. Sekolah Dasar: Kajian Teori dan Praktik Pendidikan, 157. 